Portland State University

PDXScholar

2016

\title{
Arts Integrated Elementary School Classrooms and Academic Success
}

Rachel Fackler

Portland State University

Follow this and additional works at: https://pdxscholar.library.pdx.edu/honorstheses

Let us know how access to this document benefits you.

\section{Recommended Citation}

Fackler, Rachel, "Arts Integrated Elementary School Classrooms and Academic Success" (2016).

University Honors Theses. Paper 294.

https://doi.org/10.15760/honors.243

This Thesis is brought to you for free and open access. It has been accepted for inclusion in University Honors Theses by an authorized administrator of PDXScholar. Please contact us if we can make this document more accessible: pdxscholar@pdx.edu. 
Arts Integrated Elementary School Classrooms and Academic Success

by

Rachel Fackler

An undergraduate honors thesis submitted in partial fulfillment of the requirements for the degree of

Bachelor of Science

in

University Honors

And

Art Practices

Thesis Adviser

Lis Charman

Portland State University

2016 


\section{Table of Contents}

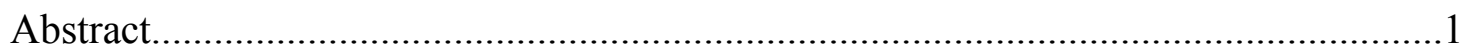

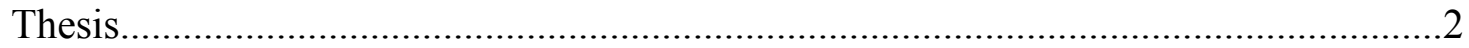

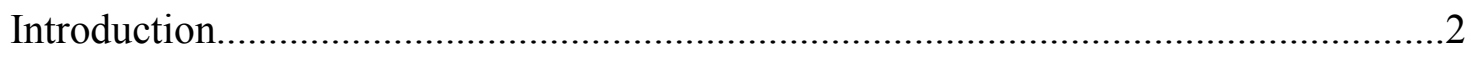

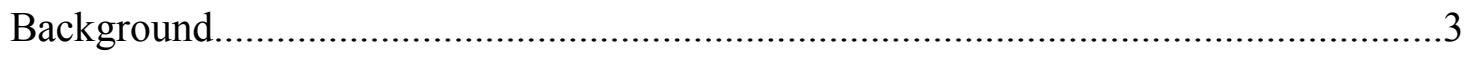

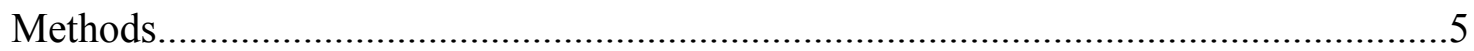

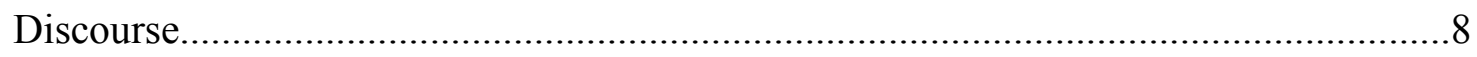

Common Core Anchor Standards and the National Core Arts Standards ...................12

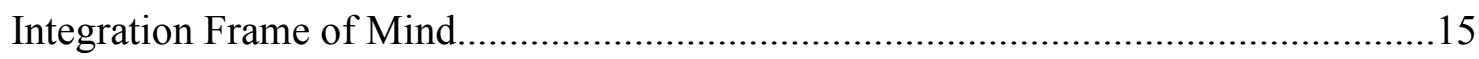

Psychology and Creativity............................................................................... 18

Organizations Working to Integrate Arts and Education.........................................19

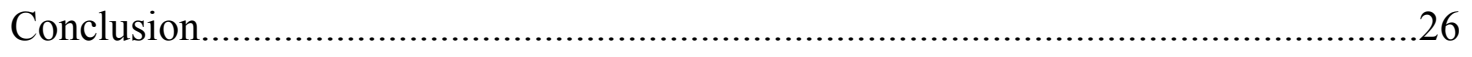

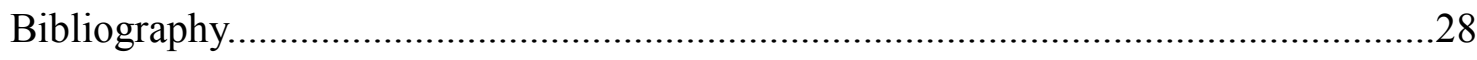




\begin{abstract}
To support academic achievement, schools must consider an arts integrated approach to lecture based learning. However, teachers, especially those from lower funded schools, who want to integrate the arts into their classrooms often have to fight and defend their reasoning for doing so. With standardized test scores often being the "end all be all" to how schools are funded and supported, arts education has been some of the first variables to be cut from schools and school districts. This is a failure to the students who need a multi-sensory approach to learning that only art can provide. Activities that activate a student's kinesthetic, visual, and auditory responses produces better on task work and motivation to learn. The arts allow students to learn in a context in which they are familiar and create a shared language with their peers and teacher. Years of research supports the claim that arts integrated learning supports academic achievement in all grade levels such as increased reading comprehension, problem solving, observational, and organizational skills.
\end{abstract}




\section{$\underline{\text { Thesis }}$}

How do the arts supplement academic achievement and learning, specifically in an elementary school setting?

\section{$\underline{\text { Introduction }}$}

I was introduced to the arts at a young age. Having been encouraged to sketch and interpret the paintings that I saw, I knew I wanted to be an artist. Art was my way of connecting the synapses in my brain. Creative writing, drawing, acting, and singing were all activities that helped me to better internalize my lessons.

I hadn't made the connection between art and education until I entered high school and began wanting to become a teacher. Philosopher, psychologist, and education reformer John Dewey describes experience as interaction between person and environmental phenomenon which would culminate in aesthetic closure. He wrote "art, in its form, unites the same relation of doing and undoing, outgoing and incoming energy that makes an experience to be an experience". ${ }^{1}$ Dewey's description of art and experience go hand in hand, giving evidence to support the idea that art will remain true to its nature even when integrated into an elementary school curriculum. A student's solution to a problem in any subject can be defined as qualitative and artistic expression if it summarizes the learning process. Thus, art and education have the ability to support each other.

\footnotetext{
${ }^{1}$ Brigham, Don L. "Art and Learning: Partners in Educational Process." Studies in Art Education 19.3 (1978): 25-32. JSTOR [JSTOR]. Web, 25.
} 


\section{Background}

My thesis and research revolves around the theory that art is integral to elementary school academic achievement. This is not specifically a how-to paper rather, this is an argument supporting integrating the arts into the classroom with a foundational frame of mind that teachers should consider. However, due to intense budget cuts, schools, public schools in particular, have had to delete art from the curriculum both by discontinuing art classes and funding towards art supplies.

Under the No Child Left Behind act of 2001, a school's worth began to be determined by the standardized test scores students received. Schools that averaged well on standardized test results were given better funding. Those who didn't had their budgets cut. This was done so that schools would be held accountable for their students' failures. Teachers were equally graded on the test performance of their students. Those whose classes didn't receive optimal test scores were more likely to be fired from the school. This caused many teachers to teach to the test. ${ }^{2}$ For obvious reasons, this isn't beneficial for any students' academic success and retention. When teachers begin to educate in a decontextualized manner, students have difficulty internalizing their lessons.

My interest in this topic could be easily explained by simply stating it's my wish to become an elementary school teacher whose curriculum will be arts integrated. However, why I want to become a teacher is a better reason for my interest in this topic. I grew up and attended elementary and high school in the midst of No Child Left Behind. I took the tests, and took the tests that were in addition to those tests. As they became more "popular" the stress that consumed me and my

\footnotetext{
${ }^{2}$ Oliver, John "Last Week Tonight with John Oliver: Standardized Testing” (HBO). Perf. John Oliver. HBO, 2015. Youtube.
} 
classmates grew, as did the stress of my teachers. Friends became afraid of being held back because they couldn't pass the OAKS (Oregon Assessment of Knowledge and Skills) test. This was often due to either not understanding the language that was used on the test due to English being a second language or because the test was contextualized in a way they weren't familiar. Another reason was that they had difficulty understanding the lessons taught by the teacher. It's a struggle that all educators face to teach their lessons quickly as there are onerous amounts of material to get through. ${ }^{3}$ This puts students who have learning disabilities or students for whom English is a second language at risk for failing a test that may harm the school's funding. Working in a creative environment allows children to work together to understand a problem or story in a language and/or context that they can understand.

What drives all of this closer to home is my brother. As the older sister to a child with Asperger's Syndrome, I believe in the importance of integrated classes even more. My brother's social and motor skills have taken constant work over the years to allow his abilities to be deemed socially acceptable. Though he has had difficulties in groups of children, group projects were crucial for him to gain those essential social skills and understand his school work. My brother and I were fortunate to live in an area that had a decent school district. However, "Oregon schools and community colleges have already faced hundreds of millions of dollars in painful cuts. Districts across the state have been forced to cut school days, lay off educators, increase class size, and eliminate valuable programs such as music, art and P.E". ${ }^{4}$

\footnotetext{
${ }^{3}$ Ms. Eliott “Arts Integration and Academic Achievement.” Interview

4 "Education Funding." Oregon Education Association. Oregon Education Association, n.d. Web. 24 Nov. 2015.
} 
Five years after No Child Left Behind was enacted, 44\% of districts had increased instruction time in elementary school English Language Arts and Math while time spent on other subjects were decreased. By 2008, 16\% of school districts had reduced class time for music and art by 35\% (57 minutes a week). In 2010, Oregon faced a budget gap of $\$ 4.2$ Billion which was reported to have been $35 \%$ of its general fund. Individual family income has dropped $10 \%$. Money for after school programs and lessons as well as rentals and art supplies have grown scarce. ${ }^{5}$

As an educator I want to habilitate an environment in which my students can flourish. Children learn in different ways which include auditory, kinesthetic, and visual practices to name a few. I don't believe that a lecture based classroom is a cognitively or socially healthy environment. Ulric Neisser, credited as the father of cognitive psychology, has written that the learner "has become what he is by virtue of what he has perceived in the past; he further creates and changes himself by what he perceives and does in the present". He describes the learning structure as a "schema" or "schemata" and agrees that multisensory perception is the instrumental activity of cognition. ${ }^{6}$

\section{Methods}

My methodology is based around the research of others and my own educational experience with the studies and essays curated and written by members of my discourse community. My research includes journals describing the correlations between arts integrated classes and academic achievement. My community is made up of educators, philosophers, artists, and psychologists.

\footnotetext{
${ }^{5}$ Wolf, Dennie Palmer. 2010 Final Evaluation The Right Brain Initiative, 4.

${ }^{6}$ Brigham, Don L. "Art and Learning: Partners in Educational Process." Studies in Art Education 19.3 (1978): 2532. JSTOR [JSTOR]. Web, 27.
} 
Throughout the course of my thesis, I've had regular meetings with my advisor Lis Charman. These meetings consisted of comprising a schedule and discussing my research and process. Lis lead me to men and women who share an interest in my discourse and actively participate in discussion. This included visiting elementary schools to conduct interviews. I've visited members of the arts and education departments here at Portland State University.

The College Board for the National Coalition for Core Arts Standards provides a detailed comparison of National Core Arts standards and Common Core state standards. Their methods cover English Language Arts, which include Reading, Writing, Speaking and Listening, Language, and Mathematics. Across all grades, the Common Core share similar organization alongside grade specific standards as well as a set of eleven standards that apply to all art disciplines, dance, media arts, music, theater, and visual arts. ${ }^{7}$

The eleven standards are:

\section{- Creating}

o 1) Generate and conceptualize artistic ideas and work

o 2) Organize and develop artistic ideas and work

o 3) Refine and complete artistic ideas and work

- Performing/Presenting/ Producing

o 4) Analyze, interpret and select artistic work for presentation

o 5) Develop and refine artistic techniques and work for presentation

\footnotetext{
${ }^{7}$ Amy Charleroy, Ardina Greco, and Nancy Rubino, comps. "The Arts and the Common Core: A Comparison of the National Core Arts Standards and the Common Core State Standards." The College Board, July 2014, 5.
} 
o 6) Convey meaning through the presentation of artistic work

- Responding

o 7) Perceive and analyze artistic work

o 8) Interpret intent and meaning in artistic work

o 9) Apply criteria to evaluate artistic work

- Connecting

o 10) Synthesize and relate knowledge and personal experiences to make art

o 11) Relate artistic ideas and works with societal, cultural, and historical context to deepen understanding ${ }^{8}$

$\underline{\text { Standards for English Language Arts: }}$

- Reading

o Responding: Understanding and evaluating how the arts convey meaning

- Perceive and analyze artistic work

- Interpret intent and meaning in artistic work

- Apply criteria to evaluate artistic work

- Speaking and Listening

o Creating: Conceiving and developing new ideas and work

- Generate and conceptualize artistic ideas and work

${ }^{8}$ Ibid. 
- Organize and develop artistic ideas and work

- Refine and complete artistic ideas and work ${ }^{9}$

$\underline{\text { Standards for Mathematics: }}$

- Make sense of problems and persevere in solving them

- Reason abstractly and quantitatively

- Construct viable arguments and critique the reasoning of others

- Model with mathematics

- Use appropriate tools strategically

- Attend to precision

- Look for and make use of structure

- Look for and express regularly in repeated reasoning ${ }^{10}$

I've actively compared and contrasted the research and methods of the current Common Core with the information attained from my interviews and readings. I've paid close attention to a project called The Right Brain Initiative which works with and studies the benefits of arts integrated educational practices to children's academics.

\section{$\underline{\text { Discourse }}$}

I am a part of a discourse of individuals interested in shaping the elementary school curriculum into something that better fits the children it serves to teach. These foundations range from general classes including math, history, and reading, among other subjects. The majority of

\footnotetext{
${ }^{9}$ Ibid., 6.

${ }^{10}$ Ibid., 8,9.
} 
my discourse has a primary focus in the belief that integrating the arts into a general curriculum would benefit all student academics. Others don't necessarily ask this question but are interested in children's interactions with creativity in other ways.

A popular research method used by the members of the arts and educational community is to go straight to the source. Community members enter schools and perform a series of studies usually in the form of summer programs or by going into classrooms during the academic year and altering the normal lesson plan to be artistically involved. Pre and post tests and interviews for students and teachers may be implemented. These would include questions as to what ways the integrated and nonintegrated classes facilitated a positive educational environment. Two classrooms may be studied at once, one as a control and another as the variable where arts would be combined with the pre-existing classes. Both classrooms would be studied for subject understanding, retention, and how the students are physically showing that they are participating in the lesson. ${ }^{11}$ Studies often last for a few weeks. Both private and public schools, and students who are "academically successful" and students who are struggling are invited to the study.

Common results from classroom based research indicated that students who were able to participate in classes that incorporated the arts did better than those who weren't. However, these studies had trouble being supported by the academic, scientific, and even political communities. ${ }^{12}$ The studies had produced onerous amounts of causational evidence supporting arts integrated education but there was little to no correlational evidence, often because of pre/post test and interview based data collection rather than closely studying how the children performed in school.

\footnotetext{
${ }^{11}$ Anderson, Alida, and Katherine Berry. "The Influence of Classroom Drama on Teachers' Language and Students' On-Task Behavior." Preventing School Failure: Alternative Education for Children and Youth 59.4 (2015): 197-206. Web, 199.

12 Brown, Neil C. M. "The Meaning of Transfer in the Practices of Arts Education." Studies in Art Education 43.1 (2001): 83-102.
} 
This is further hindered by a reluctance from school administrators to allow the arts in the classroom. Teachers who want to incorporate art into their lessons may need to defend their reasoning, especially with older elementary students. Even then, a large classroom without the help of team educators and/or lack of organizational skill could lead to unsuccessful integration. ${ }^{13}$

Part of the psychological community frames itself around the notion that Children's creativity and chaotic natures shouldn't be totally hindered. Rather, it should be supported and shaped into something more organized. Students with high creativity may have low tolerance for sitting and listening. Disruptive children are often difficult for teachers to deal with and may reprimand rather than work with student. ${ }^{14}$ Often schools teach in a decontextualized manner. This isn't conducive for the child to be able to best retain the knowledge as they can't physically or mentally connect to the material. Visual and dramatic arts bring in multiple studying and learning techniques such as the kinesthetic, verbal, visual, and auditory methods. Jean Piaget has said "you cannot teach concepts verbally; you must use a method founded on activity" as word and number languages are abstract and provoke retrieval of concepts even when they've yet to be labeled. But, if word and number languages haven't been experienced yet, they can't be brought into cognitive existence. $^{15}$

The large social and political conversation about arts integration is evidence towards its importance. However, these conversations also show that there is a grievous lack of causational research backing up supporters' claims. "Arguments made in favor of cognitive transfer, as well

\footnotetext{
${ }^{13}$ Ms. Eliott "Arts Integration and Academic Achievement." Interview

${ }^{14}$ Richards, Ruth. "Beyond Piaget: Accepting Divergent, Chaotic, and Creative Thought." New Directions for Child and Adolescent Development 1996.72 (1996): 67-86. Wiley Online Library. Web, 69.

${ }^{15}$ Brigham, Don L. "Art and Learning: Partners in Educational Process." Studies in Art Education 19.3 (1978): 25 32. JSTOR [JSTOR]. Web, 27.
} 
as arguments against, commit logical error insofar as they seek to naturalize the basis of their claims as facts". ${ }^{16}$

There are those across all discourse communities who critically question the importance of the arts and what value it holds in academia despite their support. These questions are born from the assumptions that 1) there is inherent value in the arts; 2) there is instrumental value in the arts; 3) there is unified knowledge in the arts. The majority of support for these assumptions is based around correlational research, which is problematic. Causational research is scientific and fact based. Causational evidence would best support claims such as "there is instrumental value in the arts". Correlation can be seen as coincidence. ${ }^{17}$

Whether or not integrated arts classrooms are beneficial constitutes the foundation of the majority of research for my discourse community. One way or another, they are all trying to either discover how to better educate children and/or prove that the arts benefit children. However, it's a study that needs more support. Only recently has research into this matter begun to be recognized as positive correlational evidence supporting arts integration. This is crucial in order to get the arts back into the classroom. Voters, members of the school board, and politicians decide how schools should be funded and how the funding is used. They can't make well informed decisions if they don't have the solid data to back them up. Alternatively, educators interested in integrating their classrooms may find difficulty in knowing where to start.

\footnotetext{
${ }^{16}$ Brown, Neil C. M. "The Meaning of Transfer in the Practices of Arts Education." Studies in Art Education 43.1 (2001): 83-102. Web, 98.

${ }^{17}$ Ibid.
} 


\section{Common Core Anchor Standards and the National Core Arts Standards}

A study done by The College Board compared Common Core arts standards to each of the anchor standards for English language arts and Mathematics. ${ }^{18}$ The first comparison made was between Creating and English Language practice. It was found that comparisons between Creating, to refine and complete artistic ideas and work, and the Common Core standards for Writing were most strongly aligned. 30 comparisons were made and 26 of them aligned including seven at the primary level. This is likely because both standards plan and produce original communications and/or personal expressions. There were 8 out of 10 comparisons made between Creating and Reading standards. Refining ideas relates to the process of thought as described by analyzing texts as well as interpreting them. Only 2 out of 6 comparisons between Creating and Speaking and Listening were made. ${ }^{19}$

The second comparison was between Performing/Presenting/Producing and the English Language practices. Positive alignments were found across the board. The first standard of Performing/Presenting/Producing is to analyze, interpret, and select artistic work for presentation. All ten common core anchor standards aligned for Reading in the following abilities:

- The ability to convey meaning, complex ideas, produce coherent writing, and to develop and strengthen writing.

- The ability to organize and develop ideas and to plan, revise and edit work. This is to refine artistic techniques and work to present.

\footnotetext{
${ }^{18}$ Amy Charleroy, Ardina Greco, and Nancy Rubino, comps. "The Arts and the Common Core: A Comparison of the National Core Arts Standards and the Common Core State Standards." The College Board, July 2014, 5. ${ }^{19}$ Ibid., 10.
} 
- The ability to analyze, interpret, and select work to present. ${ }^{20}$

The third comparison was in responding to work and the standards for English language practice. 29 out of the 30 comparisons that were made came up as positive alignments. 24 of these alignments were at the primary level. These standards emphasize skills and abilities related to analysis and interpretation of work. ${ }^{21}$

The fourth comparison looked into how Connecting and the Common Core Standards for English Language practice compared. This focuses on the creation and response to works of art and in relating learning to one's own knowledge and personal experience. Connection to Reading found that skills of analysis, assessment, and evaluation of text were connected to the ability to relate artistic works to deepen understanding of societal, cultural, and historical associations. Parallels to Writing found that analyzing substantive topics, relating writing style to audience and task, and demonstrating understanding of a subject require skills exemplified in the arts standards. $^{22}$

Of course as we are in the $21^{\text {st }}$ century we must consider the influence of new media and technology when looking at these comparisons. There were limitations on findings when only general Anchor Standards were being compared rather than individual grade level standards. When considering Anchor Standard for Writing \# 6: Use technology, including internet, to produce and publish writing and to interact and collaborate with others, and Anchor Standard for Speaking and Listening \#5: Make use of digital media and visual displays of data to express information and enhance understanding of presentations, both reference technology. Technology is used for almost

\footnotetext{
${ }^{20}$ Ibid.

${ }^{21}$ Ibid., 10,11.

${ }^{22}$ Ibid., 11.
} 
every art discipline. However, references to new media and technology are absent from the findings at the Anchor Standard level. This resulted in the decision that there were no technological correlations between the Common Core Anchor Standards and the National Core Arts Standards (NCAS) for Creating. ${ }^{23}$

The Common Core Anchor Standards and the National Core Arts Standards comparisons for Mathematical Practice found process-oriented approaches towards creation could be powerfully unified. Both standards speak in terms of planning work, analyzing the task or idea at hand, considering the role of context related to a particular problem or idea, and considering tools and resources available to help solve the problem. The 11 NCAS standards were compared to all 8 standards for Mathematics, a total of 88 comparisons. Of these, 63 comparisons were made. Many comparisons produced multiple areas of connection for a single standard. Mathematical Practice \#1, Make sense of problems and persevere in solving them, and the NCAS standard for Creating resulted in likenesses in generating and conceptualizing, organizing and developing, and refining and completing artistic ideas and work. ${ }^{24}$

Meaningful connections were found throughout all of the Common Core Standards and the NCAS. The majority of educators that related teachings to the NCAS combine reading texts and responding to works of art. Art and text are both practices that can be responded to and analyzed. The purpose of finding connections between the Common Core and the NCAS was not to find how art could contribute to a student's academics but to study and compare similarities in the habits and processes in standards across all subjects. The Common Core simply provides a way to describe thinking across the curriculum. However, despite the incredible number of similarities

\footnotetext{
${ }^{23}$ Ibid.

${ }^{24}$ Ibid., 11,12.
} 
between the practices for English Language Arts and Mathematics to the NCAS, the field of arts education still needs more research and resources. The arts must be clearly and permanently connected to the classroom practice..$^{25}$

The common core is the rubric teachers must comply with when educating students. Studying the parallels between the Common Core and the National Core Arts Standards gives way for educators interested in an arts integrated classroom to be able to do so without falling through on their duties. It also gives evidence to an ever growing interest and concern for keeping the arts in the classroom despite funds and classes being cut from schools across Oregon and the rest of the United States.

\section{Integration Frame of Mind}

Arts and media are closely interrelated. When incorporating arts into the classroom, an educator should be aware of the messages in art and how those messages can inform students of various subjects. These concepts and questions are generally associated with visual media, advertising and propaganda. But the same can be used to shape a curriculum. The following is a translation from media analysis to lesson development:

1) Who created this message? - How can I create/present the lesson?

2) What techniques are used to attract my attention? - What techniques can be used to attract the student's attention?

\footnotetext{
${ }^{25}$ Ibid., 12 .
} 
3) How might different people understand this message differently from me? - How may my students interpret the activity or lesson differently?

4) What lifestyles, values, and points of view are represented in or omitted from this message? What lifestyles, values, and points of view are represented or omitted in my lesson?

5) Why was this message sent? - Why am I teaching in this context? How does this teach my students? ${ }^{26}$

\section{Concepts:}

1) All media messages are "constructed. - How will I construct my lesson?

2) Media messages are constructed using a created language with its own rule. - How can I create a language that is understood by all my students?

3) Different people experience the same media message differently. - How can I make my students find shared experiences in my lesson?

4) Media have embedded values and points of view. - How are my values and points of view represented in my lesson?

5) Media is organized to gain profit and/or power. - How does my lesson profit my students and empower their knowledge of a subject? ${ }^{27}$

What are the pictures saying about a time period or subject? Instead of asking why a message was sent, ask how the message can be sent through artistic practice. Note the concepts

\footnotetext{
${ }^{26}$ Shin, Ryan, and Junghee Kim. "A Comparative Cross-Cultural Examination of Community Art Education Programs in South Korea and the United States." Studies in Art Education 55, no. 3, 299.

${ }^{27}$ Ibid.
} 
such as how media embeds values and points of view, and switch it to be how students view a concept such as gravity in a science lesson or England's search for new land to cultivate in the 1500's. How do images, projects, or activities communicate the lessons?

Student progress and understanding should always be noted and curb how a lesson is taught or enacted. No two students will understand a lesson in the same way. Every student has a different cultural background or language barrier. This must be taken into consideration when presenting a lesson. The practice of cross cultural examination has been of interest to educators since the early 70's. This gives teachers the means to question, test, and reconsider their formerly practices educational techniques. This forces them out of the culture they're familiar with and consider the aspects of others. ${ }^{28}$

Arts activities allow students and teachers to create a shared language and understanding. Group activities allow students to interact and discuss concepts with each other and further develop a shared language with their peers as well as the teacher. When studying a classroom, quantitative analysis often involves pre and post-tests. Qualitative analysis includes observing the classroom and taking notes describing changes in both students and educators. ${ }^{29}$ Children don't have to understand a subject just through the written word, they can use art to express their knowledge. ${ }^{30}$

\footnotetext{
${ }^{28}$ Ibid.

${ }^{29}$ Hui, Anna N.N., Mavis W.J. He, and Shenquan Sam Ye. "Arts Education and Creativity Enhancement in Young Children in Hong Kong." Educational Psychology: An International Journal of Experimental Education Psychology 35.3 (2015): 315-27. Web, 319-322.

${ }^{30}$ Ms. Eliott "Arts Integration and Academic Achievement." Interview
} 


\section{$\underline{\text { Psychology and creativity }}$}

In order to understand how the arts supports academic achievement we should understand how the arts affect individuals on a cognitive level. In Don L. Brigham's proposal for a "conceptual-experimental basis for the integration of art with basic learning objectives", ${ }^{31}$ he discusses the mind abstractly, representing how it curates, adopts, and contextualizes information rather than how the mind works as a biological object. ${ }^{32}$ A common theme is experience and how it is the result of interaction with the world in which the learner lives. Concepts are formed through the actions and consequences of relationships, ${ }^{33}$ a direct reference to John Dewey's belief that art and experience is closely interrelated and connected.

Students who have a hand in their own learning and problem solving appear to have a better understanding of the material presented to them. Giving students a question and some clues to the answer allows them to formulate a hypothesis and express their interpretations before conducting research to discover the truth. ${ }^{34}$ The way they come to their initial conclusions and present those ideas does not matter as long as they are able to benefit from their chosen process.

Certainly the act of integrating arts into a classroom is exceptionally chaotic, especially to educators for whom arts integration is new. Creativity is seen both as sane and insane. It's a way to judge a person's logic processes and how they turn abstract or fantastical thought into something

\footnotetext{
${ }^{31}$ Brigham, Don L. "Art and Learning: Partners in Educational Process." Studies in Art Education 19.3 (1978): 25 32. JSTOR [JSTOR]. Web, 25.

${ }^{32}$ Ibid., 27.

${ }^{33}$ Ibid., 28.

${ }^{34}$ Ibid.
} 
comprehendible and logical. The scientist Keule for example, who dreamed of a snake biting its own tale leading him to the discovery of the benzene ring. ${ }^{35}$

Unfortunately, educators may automatically reject too much unfamiliarity, or divergence, as exemplified with Keule's dream, as a potential threat before coming to know what it truly means. ${ }^{36}$ Communication and active listening is essential to the production of effective arts integration. In the classroom, those with a low IQ or willingness to follow rules but high creativity will be shunned more than those who have a high IQ and listen well but are not so creative. ${ }^{37}$ Both are examples of the social concerns behind divergent experimentation and innovation. However, the creative process isn't just how we make art or interpret the world, it's an evolutionary life saver. Without it, we wouldn't have figured out how to use fire or escape predators. ${ }^{38}$

\section{Organizations working to integrate arts and education}

\section{HEARTS}

The Higher Education, The Arts and Schools (HEARTS) addresses deficits in training teachers to teach the arts within elementary schools. They improve educator opinions towards integrating arts into their general curriculum. Beginning in 2007, HEARTS has led programs in England for student teachers (Post graduate Certificate of Education; PGCE) to become familiar with integrated education. Due to increased emphasis of training, assessment, and quality of

\footnotetext{
${ }^{35}$ Richards, Ruth. "Beyond Piaget: Accepting Divergent, Chaotic, and Creative Thought." New Directions for Child and Adolescent Development 1996.72 (1996): 67-86. Wiley Online Library. Web, 75.

${ }^{36}$ Ibid., 82.

${ }^{37}$ Ibid., 69.

${ }^{38}$ Ibid., 71.
} 
English, Mathematics, and Science curriculums, student teachers are wary to integrate the arts into their lessons. ${ }^{39}$ With strenuous focus on literacy and numeracy in the school systems, many teachers have reported an inability to participate in the arts during school hours. ${ }^{40}$

The fact that this project has been recreated and tweaked so many times is promising. They continue to criticize their own practices in order to achieve more accurate results and better outcomes for the student teachers. They also mention the reasons many student teachers may feel anxiety are strict penalties, such as being fired, if students don't perform well on their tests and a training provider must comply with government requirements. There are layers of accountability and going outside the norm can be difficult to pull off. ${ }^{41}$

\section{Turnaround Arts}

Turnaround Arts was started by the President's Committee on the Arts and the Humanities and the US Department of Education, National Endowment for the arts, local partners, and several private foundations. ${ }^{42}$ They work with 27 school districts in 15 states, One of which being the Martin Luther King School (King School) in Portland, Oregon. ${ }^{43}$ These schools are in the lowest $5 \%$ of school performance defined by the U.S. Department of Education. They bring arts education program and supplies to some of the lowest-performing elementary and middle schools in the United States. These help improve attendance, parent engagement, motivation, and academic

\footnotetext{
${ }^{39}$ Davies, Dan. "Enhancing the Role of the Arts in Primary Pre-service Teacher Education." Teaching and Teacher Education 26.3 (2010): 630-38. Web, 631.

${ }^{40}$ Ibid., 360.

${ }^{41}$ Ibid., 635.

${ }^{42}$ Turnaround Arts. Turnaround Arts. Accessed May 19, 2016. http://turnaroundarts.pcah.gov/.

${ }^{43} \mathrm{Ibid}$.
} 
achievement. Programs are integrated holistically into schools and target larger school challenges. ${ }^{44}$

The local program provides partners with coaches, expertise, methodology, evaluation, training, and peer-to-peer learning structures. The national program contributes supplies, instruments, licensing rights and kits for school musicals, and high-profile Turnaround Artists to work with students and teachers. This is a high-touch, intensive intervention model based on eight pillars that guide schools into becoming arts integrated. ${ }^{45} 46$

Turnaround Schools have shown 22.55\% improvement in Reading and $12.63 \%$ improvement in Mathematics. In Portland's King School, a 70\% reduction in both in-and-out-ofschool suspensions between 2011 and $2014 .{ }^{47}$ King School's student population is made up of $46 \%$ African American, 32\% Latino, 10\% Caucasian, 2\% Asian, and 10\% Other. $90 \%$ of students are on free or reduced price lunch and has an enrollment of 331 students. ${ }^{48}$ However, anomalies in 2012 data were questioned by the Portland Public School District, and an investigation into testing practices was conducted. As a result, practices at the school were modified.$^{49}$ King School had an attendance rate of $98.6 \%$ by $2014 .^{50}$

${ }^{44}$ Ibid.

45 "Turnaround Arts." Turnaround Arts. Accessed May 19, 2016. http://turnaroundarts.pcah.gov/.

46 Ibid. The eight pillars are: 1) Principal; 2) Art Specialists; 3) (Non-Arts) Classroom Teachers; 4) Teaching Artists; 5) Parents, Community Members, and School District Officials; 6) Comprehensive Strategic Approach; 7) ${ }^{47}$ Ibid.

${ }^{48}$ Stoelinga, Sara Ray, Yael Silk, Prateek Reddy, and Nadiv Rahman. "Final Evaluation Report: Turnaround Arts Initiative." Pcah.gov. January 2015. http://www.pcah.gov/sites/default/files/Turnaround Arts Phase 1 Final ${ }^{49}$ Ibid,. 47. Evaluation_Summary.pdf. 4

${ }^{50}$ Ibid,. 50. 
The Right Brain Initiative

Launched in 2008, the Right Brain Initiative is dedicated to integrating arts into k-12 classrooms in the Portland metropolitan area. The Right Brain Manifesto is driven by the thought that the "future will require the full measure of our thinking, it's no time to leave kids halfinterested, half-motivated, half-engaged, half-ready". This upholds a belief that current school systems only focus on the logic and order of left brain learning. The two main projects of this program are Beyond Literacy and Outwards to Community. In Beyond Literacy there is a focus on creativity, critical thinking, communication, and collaboration. Outwards to Community encourages teachers and artists to expand this framework by indicating how the arts can build communities and shared values. They have an implementation model that includes pre- and postresidency assessment of student engagement and learning, post-residency reflection, and classroom activity that extends learning beyond the bounds of the residency. ${ }^{51}$

The program collected evidence of impact via Pre-and Post-samples of students work, imagination interviews, student reflections on their $21^{\text {st }}$ century skills (creativity and innovation, critical thinking and problem solving, communication, and collaboration), and classroom observations. ${ }^{52}$ To further explain imagination interviews, conversations with students participating in the Right-Brain Initiative about their experiences. Students will look at images taken during the residency and talk about the processes of thinking. They will make/narrate drawings of their mind to describe the residency and will place markers where they felt their brains were working. ${ }^{53}$ This evidence has shown that students produce more extensive work over time.

\footnotetext{
${ }^{51}$ Wolf, Dennie Palmer. 2010 Final Evaluation The Right Brain Initiative, 1.

${ }^{52}$ Ibid., 2.

${ }^{53}$ Ibid., 13.
} 
Interviews indicate that students are engaged in a range of basic $21^{\text {st }}$ century skills. Finally, evidence supports that learning escalated when teachers (artist and classroom) and students collaborate. $^{54}$

The Right Brain Initiative strives to ensure a cost effective way to make sure arts and activities are kept in schools and teachers and principals are able to sustain practices that promote $21^{\text {st }}$ century education. It works towards the ability to train artist and classroom teachers to best handle and support specialists in art who may buckle under the weight of increased class sizes and dwindling staff.

After two years of the Right Brain initiative, they were able to adopt the Partnership for $21^{\text {st }}$ Century Skills to outline how the initiative would run. The initial evaluation was used to develop expectations for fully implemented Right Brain residencies. They created a five tiered model for inviting schools to participate and join in the initiative. ${ }^{55} 56$

Effective residencies were found to deliver high-quality arts integration in both arts and academic learning. The long-term payoff for teachers and students are focused and understood. Partnerships between teachers and artists are ensured. They reflect and improve upon the development of the program by assessing student experiences and learning. ${ }^{57}$

By 2011/2012, the number of schools participating in the Right Brain initiative grew from 20 to 44 . One school did drop out though levels of accountability had risen for core academic

\footnotetext{
${ }^{54}$ Ibid., 2.

${ }^{55}$ Ibid., 5 .

${ }^{56}$ Ibid., 11. 1) Invitational: Introduction of the concept of arts integration; 2) Entry: Professional development and program implementation in selected classrooms; 3) Infusion: Arts integration expanded to all students; 4) Immersion: Build on school-wide arts and increase school's capacity to facilitate the Right Brain model; 5) Model School (Optional): Whole-school arts integration supported by a network of other model schools

${ }^{57}$ Ibid., 10.
} 
measures and budget cuts. As of 2012, 6 of the first Right Brain schools committed to operating at the immersion level in which arts integrated and arts-based instruction were implemented in the school throughout the year. ${ }^{58}$ Students were observed to use $21^{\text {st }}$ century skills nearly twice as often as compared to ongoing classroom instruction. The children learn to think and act like artists as well as learners..$^{59}$ In three months, about $73 \%$ of participating educators reported using Right Brain strategies regularly in their classrooms. ${ }^{60}$ Teachers and principals were able to add 4 or more hours of arts (integrated) per grade level per year using their own abilities. This has allowed them to generate time and funding for field trips, hands on, project based education, and exhibiting student work. ${ }^{61}$

In 2012-2013, the Right Brain Initiative intended to undertake several initiatives. Three include work on the design and quality of residencies in schools. They will increase professional development, align with other educational efforts, and expand the evaluation of the Right Brain Initiative's work, intended for the near future. As for the long term, voters in the city of Portland passed Measure 26-146 which established an Arts Education and Access Fund. This would allow access to the certified arts instruction every week for K-5 elementary schools. ${ }^{62}$

In six years the Right Brain Initiative worked with 13,564 students, 49 schools, 55 teaching artists, 857 teachers and school staff, and spent 3,000 hours of individual development. By this sixth year, they were able to correlate arts integrated schooling with an increase in test scores. ${ }^{63}$

\footnotetext{
${ }^{58}$ Wolf, Dennie Palmer. The Right Brain Initiative Evaluation Report: 2011-2012, 1.

${ }^{59}$ Ibid., 2.

${ }^{60}$ Ibid., 3.

${ }^{61}$ Ibid., 4.

${ }^{62}$ Ibid., 5.

${ }^{63}$ The Right Brain Initiative 2014 Progress Report, 1
} 
During interviews with students, $75 \%$ were noted to exhibit understanding that their abilities were open to change as long as they worked on it. $1^{\text {st }}$ graders at quantum elementary in Hillsboro showed that $80 \%$ of students from a class comprised of $50 \%$ English language learners doubled their letter recognition scores after working with My Voice Music, a partner organization to The Right Brain Initiative. ${ }^{64}$

By 2015 19,324 students were served. 55\% of students were Caucasian, 26\% Latino/Hispanic. 7\% African-American, 7\% Multi-Ethnic, and 5\% of students were Asian/Pacific Islander. $55 \%$ of students are on free or reduced lunch. ${ }^{65}$

The Right Brain initiative continues to collect data on how students' progress through their program and in other classes. From a $3^{\text {rd }}$ grader discovering geometric principles through making mandalas to $1^{\text {st }}$ graders understanding basic concepts of circuitry with $3 \mathrm{D}$ wire sculptures that lit up, ${ }^{66}$ test scores have continued to increase as years with The Right Brain initiative pass. ${ }^{67}$ They were granted a \$210,000 grant from The Oregon Community Foundation and raised nearly $\$ 17,000$ through Willamette Week's “Give!” drive. ${ }^{68}$ Total funding for The Right Brain Initiative totaled to $\$ 1,064,501$. Only $\$ 275,048$ of the money came from school districts and $\$ 158,350$ from the city of Portland. ${ }^{69}$

\footnotetext{
${ }^{64}$ Ibid., 3.

${ }^{65} 2015$ The Right Brain Initiative Progress Report, 2.

${ }^{66}$ Ibid., 3.

${ }^{67}$ Ibid., 4.

${ }^{68}$ Ibid., 5.

${ }^{69}$ Ibid., 10.
} 


\section{Conclusion}

Teachers who work in an arts integrated setting have been able to experience firsthand the wonders that arts integrated education does for children. The arts encourage free thinking and organically develop thinking skills, as well as build self-confidence. ${ }^{70}$ Through efforts from organizations such as The Right Brain initiative, and Measure 26-146 establishing an arts education fund for Portland schools, the arts are being brought back into the classroom. At least in Portland, Oregon. Unfortunately, substantial work is needed to create permanent art programs in all of Oregon's Schools.

The intention of my thesis wasn't so much to create a concrete guideline for teachers who were interested in creating an arts integrated curriculum rather, it's a framework to support arts integration. With school budgets continually being cut, and arts programs being removed it's difficult to study exactly how much the arts impact academic performance. While there are programs such as The Right Brain Initiative, Turnaround Arts, and HEARTS to support schools who want an arts integrated curriculum, these are not always affordable or easily accessible (HEARTS is based out of England). However, they are still quality resources for educators and schools and are always available for consultation.

Arts integration is a reenactment of direct learning. The arts incorporate total engagement physically, intellectually, and visually. It requires human interaction, technology, and living the lesson. For example, a class of advanced math students who use quilting as a means to study geometry loved every moment of it and excelled in their studies. ${ }^{71}$ For this evidence alone, arts

\footnotetext{
${ }^{70}$ Jenkins, Laura. “Arts Integration and Academic Achievement.” Interview

${ }^{71} \mathrm{Ibid}$,
} 
integrated education must be supported. This concept isn't just about kids being artists, it's about how children experience an integrated arts classroom. Children become less shy when allowed to stretch their fingers and their brains, and the things they begin to understand and discuss is incredible. $^{72}$

${ }^{72}$ Ibid,. 


\section{Bibliography}

Amy Charleroy, Ardina Greco, and Nancy Rubino, comps. "The Arts and the Common Core: A Comparison of the National Core Arts Standards and the Common Core State Standards." The College Board, July 2014.

Anderson, Alida, and Katherine Berry. "The Influence of Classroom Drama on Teachers' Language and Students' On-Task Behavior." Preventing School Failure: Alternative Education for Children and Youth 59.4 (2015): 197-206. Web.

Brown, Neil C. M. "The Meaning of Transfer in the Practices of Arts Education." Studies in Art Education 43.1 (2001): 83-102. Web.

Brigham, Don L. "Art and Learning: Partners in Educational Process." Studies in Art Education 19.3 (1978): 25-32. JSTOR [JSTOR]. Web

Davies, Dan. "Enhancing the Role of the Arts in Primary Pre-service Teacher Education." Teaching and Teacher Education 26.3 (2010): 630-38. Web.

"Education Funding." Oregon Education Association. Oregon Education Association, n.d. Web. 24 Nov. 2015.

Hui, Anna N.N., Mavis W.J. He, and Shenquan Sam Ye. "Arts Education and Creativity Enhancement in Young Children in Hong Kong." Educational Psychology: An International Journal of Experimental Education Psychology 35.3 (2015): 315-27. Web.

Jenkins, Laura. "Arts Integration and Academic Achievement." Interview.

Jolls, Tessa, and Denise Grande. Arts Education Policy Review 107.1 (2005): 25-31. Web. 
Kindler, Anna M. "A Review of Rationales for Integrated Arts Programs." Studies in Art Education 29.1 (1987): 52-60. JSTOR [JSTOR]. Web.

Ms. Eliott “Arts Integration and Academic Achievement.” Interview

Oliver, John Last Week Tonight with John Oliver: Standardized Testing (HBO). Perf. John Oliver. HBO, 2015. Youtube.

Richards, Ruth. "Beyond Piaget: Accepting Divergent, Chaotic, and Creative Thought." New Directions for Child and Adolescent Development 1996.72 (1996): 67-86. Wiley Online Library. Web.

Shin, Ryan, and Junghee Kim. "A Comparative Cross-Cultural Examination of Community Art Education Programs in South Korea and the United States." Studies in Art Education 55, no. 3

Stoelinga, Sara Ray, Yael Silk, Prateek Reddy, and Nadiv Rahman. "Final Evaluation Report: Turnaround Arts Initiative." Pcah.gov. January 2015. http://www.pcah.gov/sites/default/files/Turnaround Arts Phase 1 Final Evaluation_Summary.pdf. 4

The Right Brain Initiative 2014 Progress Report.

Turnaround Arts. Turnaround Arts. Accessed May 19, 2016. http://turnaroundarts.pcah.gov/.

2015 The Right Brain Initiative Progress Report.

Wolf, Dennie Palmer. 2010 Final Evaluation The Right Brain Initiative.

Wolf, Dennie Palmer. The Right Brain Initiative Evaluation Report: 2011-2012. 